\title{
Genetic Diversity Analysis of Okra Genotypes Using Morphological Markers
}

\author{
Davinder Singh ${ }^{*}$, B.S. Dudi, S.K. Dhankhar and Rajkumar \\ Department of Vegetable Science, C. C. S. Haryana Agricultural University, \\ Hisar-125004, Haryana, India \\ *Corresponding author
}

\section{Keywords \\ Okra, Genetic \\ diversity, \\ Mahalanobis $\mathrm{D}_{2}$ \\ statistics, Cluster \\ analysis}

\section{Article Info}

Accepted:

14 December 2017

Available Online:

10 January 2018

\section{A B S T R A C T}

Genetic divergence of 30 okra genotypes was studied using Mahalanobis D2 statistics revealed that considerable genetic diversity among genotypes in okra. Thirty diverse genotypes were grouped into six clusters with the highest of 11 genotypes in the cluster II, 10 in the cluster I, 4 genotypes in the cluster III, 3 in cluster V and 1 in each IV and VI cluster. The inter cluster distance was higher than the intra cluster distance indicating wide genetic diversity among the genotypes of different groups. The cluster means of 10 characters among six clusters indicated that high genetic variability range present for fruit yield per plant (174.7 $\mathrm{g}$ in cluster V to $350.14 \mathrm{~g}$ in cluster III), followed by fruits/plant (20.83 in cluster V to 40.03 in cluster III) and average weight of fruit ( $7.667 \mathrm{~g}$ in cluster IV to $10.033 \mathrm{~g}$ in cluster VI). The relative contribution of studied characters indicated that branches per plant had contributed highest $(41.61 \%)$ followed by fruit yield per plant $(31.49 \%)$, fruits per plant $(15.17 \%)$, nodes (1st Flowering node to end) (8.97), stem diameter (1.61). Based on principal component analysis (PCA), the first four components explained $87.83 \%$ of total genetic variation. These characters are highly genetic variable and genotype having these characters in different cluster could be used in breeding programme to develop high yielding cultivars in okra.

\section{Introduction}

Okra [Abelmoschus esculentus (L.) Moench] usually denoted as Lady's finger belongs to the Malvaceae family (Kishor et al., 2016) and an important and extensively cultivated, annual crop in both the tropical and subtropical provinces of the world (Eshiet and Brisibe, 2015; Ali et al., 2014). It is a vegetable rich in organicand inorganic nutrients like vitamins and mineral salts, including calcium; which are often lacking in diet (Chattopadhyay et al., 2011; Rahman et al., 2012), further containing $86.1 \%$ water, 2.2 $\%$ protein, $0.2 \%$ fat, $9.7 \%$ carbohydrate, $1.0 \%$ fiber and $0.8 \%$ ash (Saifullah and Rabbani, 2009). The fruits of okra, usually called "pod" which contain digestible fiber, low calories and fat-free contents (Kumar and Sreeparvathy, 2010; Reddy et al., 2013) and consumed as salads, boiled and fried vegetables (Daniela et al., 2012) further the fruits are used for soups and stews thickening due to its mucilaginous and tender texture 
nature, (Ijoyah \& Dzer, 2012; Das et al., 2013). Tropical Africa is proposed origin of okra from where it spreaded to America, Asia, Southern Europe and other countries (Muhammad et al., 2013).In 2008, India was one of the five top okra producing countries in the world (FAOSTAT, 2010).

The strength and value of germplasm depends on two factors, the number of accessions it contains and the diversity present in those accessions (Ren et al., 1995). For the balanced use of plant genetic resources, characterization and quantification and information on the genetic diversity within and among closely related crop varieties is essential. Genetic diversity is prerequisites for any successful breeding programme. Use of genetically diverse parents in recombination breeding supposed to give maximum heterosis in F1's and the importance of genetic diversity in selecting the parents has been continually emphasized by lot of workers (Murthy and Anand, 1996; Pillai, 2002).Diversity based on morphological characters generally varies with environments therefore evaluation of traits needs growing the plants to full adulthood prior to identification. Omonhinmin and Osawaru (2005) stated that great degree of wide morphological difference exist between accessions of okra, especially in West African type. Hence, estimation of genetic divergence of economically important characters based on sound statistical procedures like MahanalobisD2statistics is required to identify diverse genotypes for crossing. In determining genetic divergence, cluster analysis is one of the powerful tools among different varieties of crops.

Lack of relationship between the genetic diversity and geographical distance indicated that forces like natural and artificial selection, exchange of genetic materials, genetic drift and spontaneous mutation could lead to genetic diversity instead of geographical origin (Pradip et al., 2010; Seth et al., 2016). Therefore, selection for outcrossing of okra cultivars ought to base on genetic diversity instead of geographic diversity.

\section{Materials and Methods}

\section{Experimental location}

The material for the present experimental investigation contained thirty genotypes of okra conserved at the research farm of the Department of Vegetable Science, C.C.S. Haryana Agricultural University, Hisar, during kharif season 2013.

\section{Field evaluation and data collection}

The experiment was laid out in randomized complete block design (RCBD) with three replications. In each replication each genotype was grown in a double row plot of size $2.1 \mathrm{~m}$ $\times 1.20 \mathrm{~m}$ accommodating 14 plants with rowto-row spacing of $60 \mathrm{~cm}$ and plant-to-plant spacing of $30 \mathrm{~cm}$. Two seeds per hill were sown and later thinned to one plant per hill. Recommended package of practices were followed to raise a healthy crop.

The data on ten quantitative characters were recorded on five competitive plants of each genotype selected randomly in each replication. Data were collected on number of nodes (upto end including the first flowering node), days to $50 \%$ flowering, plant height (cm), number of branches per plant, stem diameter $(\mathrm{cm})$, diameter of edible fruit (cm),number of fruits per plant, internodal length $(\mathrm{cm})$, fruit weight $(\mathrm{g})$, fruit yield per plant $(\mathrm{g})$.

\section{Data analysis}

Genetic diversity between groups was estimated by using D2 statistics given by Mahalanobis (1936) following the procedure 
given by Rao (1952). The mean values were computed to calculate D2 values between all possible pairs of genotypes. The grouping of genotypes was done using Tocher's method as described by Rao (1952).Genetic diversity in okra germplasm with the practice of cluster analysis had earlier been stated by several researchers (Akotkar et al., 2010; Umrao et al., 2014; Seth et al., 2016).

\section{Results and Discussion}

Genetic divergence among 30 genotypes for 10 characters was made by using Mahalanobis D2 analysis as per Rao (1952). Based on Mahalanobis D2 analysis, 30genotypes were grouped into six clusters, on the basis of observed smaller D2 values among genotypes within a cluster than those belonging to different cluster following Tocher's methods (Fig. 1). Out of the six clusters, Cluster II contains maximum number of 11 genotypes followed by cluster I with 10 genotypes, cluster III with 4 genotypes and cluster $\mathrm{V}$ with 3 genotypes while cluster IV and VI have 1 genotype each. The six different clusters with respective cultivars and their numbers are presented in Table 1 . It is indicating that Cluster IV and cluster VI are more diverse from resting other clusters. The genotypes in these clusters are more genetically diverse and may be used as potential parents for breeding programmes to develop high yielding cultivars. It was also observed that geographical distance between the genotypes had no relation with the genetic divergence as the genotypes from same source had fallen into different clusters as well as the same cluster contained genotypes from different sources. It indicates that clustering pattern of okra genotypes did not follow their geographic distribution. These findings are in agreement to earlier reports of Bindu et al., (1994), Mishra et al., (1996), Dhaduk et al., (2004), Reddy et al., (2012), Ab.Mazid et al., (2013) in okra.
Widely varied inter-cluster distances in the six clusters of okra cultivars are shown in Table 2. Average intra and inter cluster D2 values, indicating nature of genetic divergence at intra and inter cluster levels, respectively. The D2 values of intra cluster and inter cluster ranged from 0.0 to 71.80 and 35.94 to 360.94 respectively. Maximum intra cluster distance was observed in cluster III (71.80) followed by cluster $\mathrm{V}$ (59.37) and minimum intra cluster distance in cluster IV and VI. Inter cluster distance was maximum in between cluster III and cluster V (360.94) followed by cluster IV and V (334.82) and cluster I and VI (263.90) while minimum inter cluster distance was observed in cluster I and IV (35.94) followed by cluster I and II (57.02) and cluster III and VI (128.0). In general, inter cluster distance was much more than intra cluster distances. This suggesting that within cluster genotypes have same genetic constitution i.e., homogeneous are less divergent than those occurred in a different cluster.

Therefore, genotypes belonging to these inter clusters may be used in hybridization programme to obtain transgressive segregants with broad spectrum of genetic variability for yield and other component traits to isolate high yielding genotypes in okra. These results are in accordance with the finding of Vahab et al., (1994), Bisht et al., (1995), Mishra et al., (1996). Outcrossing the cultivars featuring in these clusters could enhance transgressive segregations and generation progress. This has been as earlier opined by Umrao et al., (2014) and Seth et al., (2016). Conclusively, an involvement of highest yielding cultivars, could be exploited directly or hybridized to enhance novel recombinants and exploit transgressive segregates with high genetic yield potentials.

As high yield and earliness is a prime objective in any breeding programme, cluster those having high means for fruit yield per 
plant, and its components traits need to be considered for selection of genotypes for breeding programme. The cluster means for 10 characters (Table 3) indicated that considerable variability present in characters among the six clusters. The data showed that maximum cluster mean variation was observed for fruit yield per plant $(174.7 \mathrm{~g}$ in cluster $\mathrm{V}$ to $350.14 \mathrm{~g}$ in cluster III), average weight of fruit $(7.667 \mathrm{~g}$ in cluster IV to 10.033 $\mathrm{g}$ in cluster VI) and fruits/plant (20.83 in cluster V to 40.03 in cluster III).

Table.1 Six different clusters with respective cultivars and their numbers

\begin{tabular}{|c|c|c|c|c|c|c|c|c|c|c|c|c|}
\hline \multirow{2}{*}{$\begin{array}{l}\text { Sr. No. } \\
\text { Cluster } \\
1 \text { 1. }\end{array}$} & \multirow{2}{*}{$\begin{array}{l}\begin{array}{l}\text { No. of } \\
\text { genotypes }\end{array} \\
10\end{array}$} & \multicolumn{11}{|c|}{ Name of genotype } \\
\hline & & $\begin{array}{l}\text { HRB } \\
114- \\
1-1\end{array}$ & $\begin{array}{l}\text { HRB- } \\
122- \\
1-1\end{array}$ & $\begin{array}{l}\text { HRB- } \\
109- \\
1-1\end{array}$ & $\begin{array}{l}\text { HRB- } \\
138- \\
1-1\end{array}$ & $\begin{array}{l}\text { HRB- } \\
105- \\
1-1\end{array}$ & $\begin{array}{l}\text { HRB- } \\
147- \\
1-1\end{array}$ & $\begin{array}{l}\text { HRB- } \\
163- \\
1-1\end{array}$ & $\begin{array}{l}\text { HRB- } \\
162- \\
1-1\end{array}$ & $\begin{array}{l}\text { HRB- } \\
151- \\
2-1\end{array}$ & $\begin{array}{l}\text { HRB- } \\
141- \\
2-1\end{array}$ & \\
\hline 2. & 11 & $\begin{array}{l}\text { HRB } \\
143- \\
2-2\end{array}$ & $\begin{array}{l}\text { HRB- } \\
140- \\
2-1\end{array}$ & $\begin{array}{l}\text { HRB- } \\
119- \\
1-1\end{array}$ & $\begin{array}{l}\text { HRB- } \\
108- \\
1-1\end{array}$ & $\begin{array}{l}\text { HRB- } \\
151- \\
1-1\end{array}$ & $\begin{array}{l}\text { HRB- } \\
152- \\
1-1\end{array}$ & $\begin{array}{l}\text { HRB- } \\
113- \\
1-1\end{array}$ & $\begin{array}{l}\text { HRB- } \\
140- \\
2-2\end{array}$ & $\begin{array}{l}\text { HRB- } \\
141- \\
1-1\end{array}$ & $\begin{array}{l}\text { HRB- } \\
124- \\
3-1\end{array}$ & $\begin{array}{l}\text { HRB- } \\
106- \\
1-1\end{array}$ \\
\hline 3. & 4 & $\begin{array}{l}\text { HRB } \\
146- \\
1-1-2\end{array}$ & $\begin{array}{l}\text { HRB- } \\
108- \\
2-2\end{array}$ & $\begin{array}{l}\text { HRB- } \\
107- \\
4-1\end{array}$ & $\begin{array}{l}\text { HRB- } \\
153- \\
2-1\end{array}$ & & & & & & & \\
\hline 4. & 1 & $\begin{array}{l}\text { HRB } \\
141-1\end{array}$ & & & & & & & & & & \\
\hline 5. & 3 & $\begin{array}{l}\text { HRB } \\
132- \\
1-1\end{array}$ & $\begin{array}{l}\text { HRB- } \\
130- \\
1-1\end{array}$ & $\begin{array}{l}\text { HRB- } \\
147- \\
2-1\end{array}$ & & & & & & & & \\
\hline 6. & 1 & $\begin{array}{l}\text { HRB } \\
124- \\
1-1\end{array}$ & & & & & & & & & & \\
\hline
\end{tabular}

Table.2 Average Intra (diagonal) and Inter cluster distance (D2) for okra genotypes

\begin{tabular}{|l|r|r|r|r|r|r|}
\hline & 1 Cluster & 2 Cluster & 3 Cluster & 4 Cluster & 5 Cluster & 6 Cluster \\
\hline $\mathbf{1}$ Cluster & $\mathbf{2 0 . 7 1}$ & 57.02 & 183.43 & 35.94 & 104.27 & 263.90 \\
\hline $\mathbf{2}$ Cluster & & $\mathbf{3 4 . 3 0}$ & 102.81 & 101.14 & 212.47 & 228.34 \\
\hline $\mathbf{3}$ Cluster & & & $\mathbf{7 1 . 8 0}$ & 216.26 & 360.94 & 128.00 \\
\hline $\mathbf{4}$ Cluster & & & & $\mathbf{0 . 0 0}$ & 65.86 & 233.27 \\
\hline $\mathbf{5}$ Cluster & & & & & & \\
\hline
\end{tabular}


Table.3 Cluster mean for different characters in 30 okra genotypes by Tocher method

\begin{tabular}{|c|c|c|c|c|c|c|c|c|c|c|}
\hline Cluster & $\begin{array}{r}\text { Plant } \\
\text { Height } \\
\text { cm }\end{array}$ & $\begin{array}{r}\text { Branches } \\
\text { /Plant }\end{array}$ & $\begin{array}{r}\text { Stem } \\
\text { Diameter } \\
(\mathbf{c m})\end{array}$ & $\begin{array}{r}\text { Nodes (1st } \\
\text { Flowering } \\
\text { Node to } \\
\text { End) }\end{array}$ & $\begin{array}{r}\text { Days to } \\
50 \% \\
\text { Flowering }\end{array}$ & $\begin{array}{r}\text { Diameter } \\
\text { of Edible } \\
\text { Fruit } \\
(\mathrm{cm})\end{array}$ & $\begin{array}{l}\text { Fruits } \\
\text { /Plant }\end{array}$ & $\begin{array}{r}\text { Internodal } \\
\text { Length } \\
(\mathrm{cm})\end{array}$ & $\begin{array}{r}\text { Fruit } \\
\text { Weight } \\
\text { (g) }\end{array}$ & $\begin{array}{r}\text { Fruit } \\
\text { Yield/ } \\
\text { Plant } \\
\text { (g) }\end{array}$ \\
\hline 1 Cluster & 98.960 & 4.898 & 1.821 & 12.497 & 43.700 & 1.500 & 28.493 & 530 & 8.510 & 242.037 \\
\hline 2 Cluster & 99.327 & 5.279 & 1.862 & 755 & 44.636 & 1.461 & 35.504 & 5.258 & 8.206 & 291.552 \\
\hline 3 Cluster & 98.192 & 3.963 & 1.770 & 16.592 & 43.250 & 1.217 & 40.039 & 5.383 & 8.775 & 350.142 \\
\hline 4 Cluster & 92.633 & 3.533 & 1.740 & 8.000 & 46.000 & 1.400 & 26.467 & 5.100 & 7.667 & 203.367 \\
\hline 5 Cluster & 97.644 & 3.422 & 1.761 & 9.433 & 43.333 & 1.322 & 20.833 & 4.989 & 8.422 & 174.667 \\
\hline 6 Cluster & 107.600 & 2.000 & 2.593 & 17.367 & 47.000 & 1.467 & 33.267 & 5.633 & 10.033 & 332.967 \\
\hline
\end{tabular}

Table.4 Percent contribution of different traits in total variation

\begin{tabular}{|l|}
\hline Source \\
\hline 1 Plant Height cm \\
\hline 2 Branches /Plant \\
\hline 3 Stem Diameter $(\mathrm{cm})$ \\
\hline 4 Nodes (1st Flowering Node \\
\hline 5 Days to 50\% Flowering \\
\hline 6 Diameter of Edible Fruit \\
\hline 7 Fruits /Plant \\
\hline 8 Internodal Length $(\mathrm{cm})$ \\
\hline 9 Fruit Weight (g) \\
\hline 10 Fruit Yield/ Plant $(\mathrm{g})$ \\
\hline
\end{tabular}

\begin{tabular}{|r|r|}
\hline Contribution \% & Times Ranked $\mathbf{1}^{\text {st }}$ \\
\hline 0.23 & 1.000 \\
\hline 41.61 & 181.000 \\
\hline 1.61 & 7.000 \\
\hline 8.97 & 39.000 \\
\hline 0.69 & 3.000 \\
\hline 0.23 & 1.000 \\
\hline 15.17 & 66.000 \\
\hline 0.01 & 0.000 \\
\hline 0.01 & 0.000 \\
\hline 31.49 & 137.000 \\
\hline
\end{tabular}

Table.5 Principal component analysis of the 30 okra genotype showing the factor scores, Eigen values and percentage total variance accounted by the four principal component axes

\begin{tabular}{|l|r|r|r|r|}
\hline & PC1 & \multicolumn{1}{|c|}{ PC2 } & \multicolumn{1}{|c|}{ PC3 } & \multicolumn{1}{|c|}{ PC4 } \\
\hline Plant Height cm & 0.199 & 0.052 & 0.790 & 0.191 \\
\hline Branches /Plant & 0.236 & -0.462 & -0.052 & 0.061 \\
\hline Stem Diameter (cm) & -0.072 & 0.429 & 0.292 & 0.305 \\
\hline Nodes (1st Flowering Node to End) & 0.432 & 0.217 & 0.161 & -0.017 \\
\hline Days to 50\% Flowering & -0.311 & 0.381 & -0.162 & 0.133 \\
\hline Diameter of Edible Fruit (cm) & -0.176 & 0.056 & 0.321 & -0.895 \\
\hline Fruits /Plant & 0.445 & 0.183 & -0.277 & -0.130 \\
\hline Internodal Length (cm) & -0.397 & 0.239 & -0.085 & 0.003 \\
\hline Fruit Weight (g) & 0.129 & 0.504 & -0.134 & -0.101 \\
\hline Fruit Yield/ Plant (g) & 0.461 & 0.244 & -0.175 & -0.144 \\
\hline Eigene Value (Root) & $\mathbf{3 . 4 1 4}$ & $\mathbf{3 . 2 1 5}$ & $\mathbf{1 . 2 3 9}$ & $\mathbf{0 . 9 1 5}$ \\
\hline Partial variance (\%) & $\mathbf{3 4 . 1 4 0}$ & $\mathbf{3 2 . 1 5 3}$ & $\mathbf{1 2 . 3 9 2}$ & $\mathbf{9 . 1 5 1}$ \\
\hline Cum. Var. Exp. (\%) & $\mathbf{3 4 . 1 4 0}$ & $\mathbf{6 6 . 2 9 3}$ & $\mathbf{7 8 . 6 8 5}$ & $\mathbf{8 7 . 8 3 6}$ \\
\hline
\end{tabular}


Fig.1 Dendrogram showing distribution of 30 okra genotype based upon 10 quantitative traits

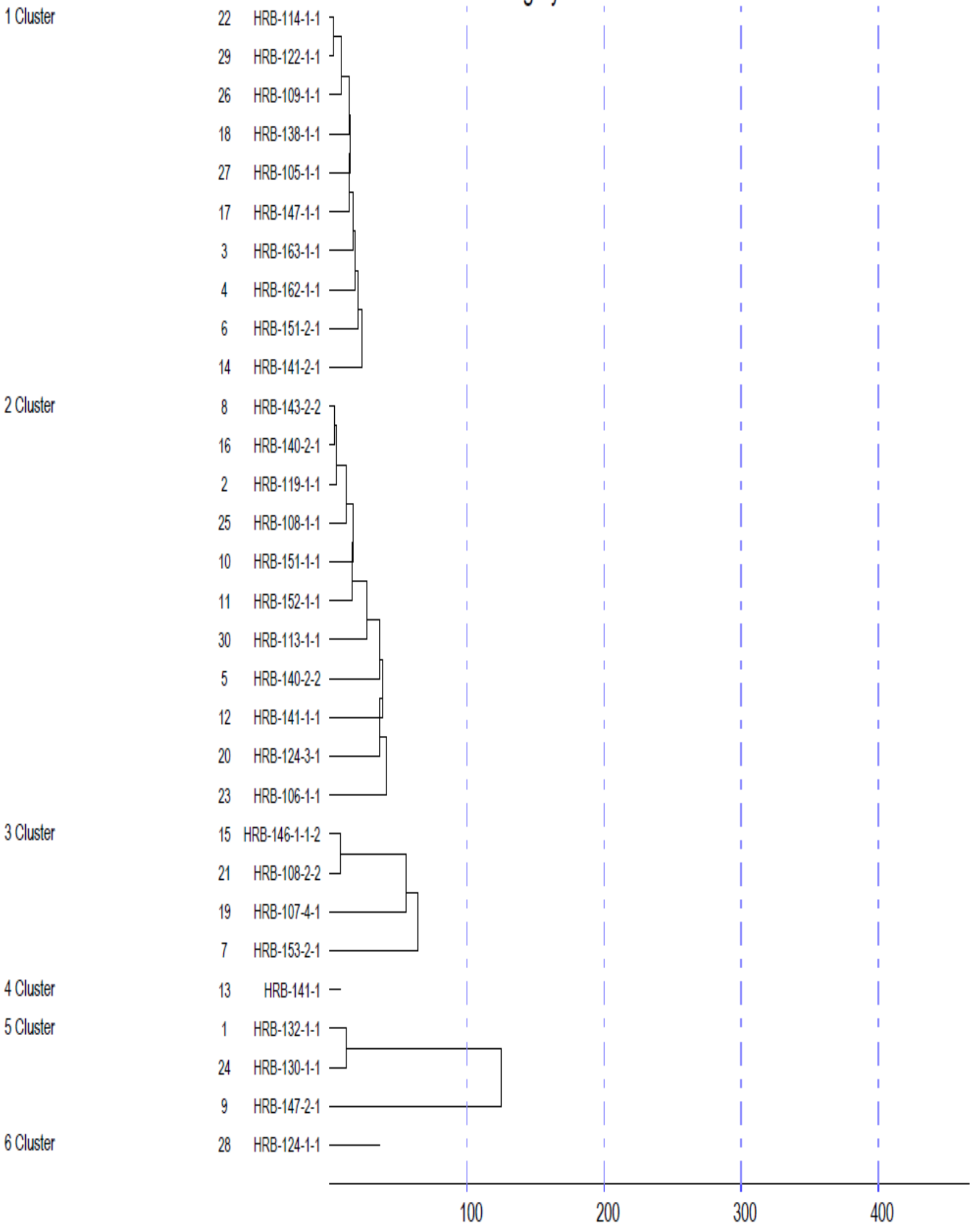


It was observed that cluster VI genotype has highest desirable cluster mean for six characters followed by cluster III for two characters, one characters in each cluster II and cluster. Cluster VI recorded highest mean for plant height $(107.60 \mathrm{~cm})$, stem diameter $(2.593 \mathrm{~cm})$, number of nods per plant $(1 \mathrm{st}$ flowering node to end) (17.36), days to $50 \%$ flowering (47.0), internodal length $(5.63 \mathrm{~cm})$, and fruit weight $(10.03 \mathrm{~g})$. Cluster III recorded highest desirable cluster mean for fruits per plant (40.03), fruit yield per plant $(350.14 \mathrm{~g})$. Cluster I and cluster II have desirable cluster mean for diameter of edible fruit $(1.50 \mathrm{~cm})$ and branches per plant (5.28) respectively. Therefore, divergent genotypes should be selected from the clusters III and VI for hybridization programme.

An assessment of relative contribution of ten characters towards total genetic divergence (Table 4) revealed that branches per plant had contributed highest $(41.61 \%)$ by taking 181 times first ranking followed by fruit yield per plant $(31.49 \%)$ by 137 times, fruits per plant $(15.17 \%)$ by 66 times, nodes (1st Flowering node to end) (8.97)by 39 times, stem diameter (1.61) by 7 times, It suggested that these characters are highly genetic variable and these characters should be considered while selecting parents for hybridization programmes under studied genotypes. John et al., (1992), Abdul et al., (1994), Kumari and Chaudhury (2006), also observed contribution of plant height, fruit length and weight of fruits towards the genetic divergence. with contrast to this plant height $\mathrm{cm}$, Days to $50 \%$ flowering, diameter of edible fruit, internodal length $(\mathrm{cm})$ and fruit weight $(\mathrm{g})$ had very low contribution as $0.23 \%, 0.69 \%, 0.23 \%, 0.01$ $\%$ and $0.01 \%$ respectively. The cumulative proportion of variation explained by the four PC-axes, 87.836\% (Table 5) compared well with observations made by Campos et al., (2005) and Ogunbayo et al., (2005) that the PC-axes contributed 76.62 and $64.5 \%$ variations, respectively. Similarly, Ahiakpa et al., (2013) reported that the first four PC- axis contributed $82.97 \%$ of the variations in okra. Branches per plant, nodes $\left(1^{\text {st }}\right.$ flowering node to end), days to $50 \%$ flowering, intermodal length, fruits per plant and fruit yield contributed to the variation in PC1.Branches per plant, stem diameter, nodes $\left(1^{\text {st }}\right.$ flowering node to end), days to $50 \%$ flowering, internodal length, fruit weight and fruit yield accounted for the variations observed in PC2. Plant height, stem diameter, diameter of edible fruit and fruits per plant contributed to the variations in PC3. Stem diameter and diameter of edible fruit contributed to variations in PC4. These variations may suggest the existence of genetic diversity in okra that can be harnessed to improve the crop. Similar observation was made by Yonas et al., (2014).

The present study was carried out to examine the nature and magnitude of genetic divergence in 30 genotypes of okra. A better understanding of the extent of genetic diversity among okra germplasms is necessary for planning selection programme aimed at improvement of yield. Realizing the importance of developing high yielding okra genotypes, the present study was undertaken to assess the genetic diversity of okra germplasms for various agro-morphological traits. From the above findings it can be concluded that, genotypes from high divergent clusters contain wide genetic diversity for different traits under studied, are expected to yield potential $\mathrm{F} 1 \mathrm{~s}$ and transgressive seggregants for further exploitation and hence, these findings are in conformity with earlier reports of Hazara et al., (2002) and Bendale et al., (2003)

\section{References}

Ab. Mazid, S. M. S. A. M., Mohrir, M. N and Jadhav, R. S. 2013. Genetic divergence in okra (Abelmoschus esculentus L. Moench.). 
Electron. J. Plant Breed., 4 (3): 1258-1260.

Abdul, M. V., Nirmala Devi, S., Mathew, S. K. and Prabhakaran, P. V. 1994. Genetic divergence in okra. Hort. J. 7: 117-120.

Ahiakpa JK, Kaledzi PD, Adi EB, Peprah S, Dapaah HK 2013. Genetic diversity, correlation and path analyses of okra (Abelmoschus spp. (L.) Moench) germplasm collected in Ghana. Int. J. Dev. Sust. 2(2):1396-1415.

Akotkar, P.K., D. K. De and A. K. Pal. 2010. Genetic variability and divergence in okra (Abelmoschus esculentus L. Moench). Electronic Journal of Plant Breeding, 1(4), 393-398.

Ali AS, Shah H, Gul R, Ahmad H, Nangyal H, Sherwani KS 2014. Morpho-Agronomic Characterization of Okra (Abelmoscus esculentus L.). World App. Sc. J. 31(3):336-340.

Bendale, V.W., Atanur, S.S., Bhave, S.C., Mehta, J.L. and Pethe, U.B. 2003. Genetic divergence for yield and yield components in okra. Orissa J. Hort., 31: 30-33.

Bindu, K. K., Manju, P. and Sarashwathy, P. 1994. Genetic divergence in bhindi [Abelmoschus esculentus (L.) Moench]. J. Trop. Agric., 32 (2): 115-117.

Bisht, I. S., Mahajan, R. K. and Rana, R. S. 1995. Genetic diversity in South Asian okra [Abelmoschus esculentus (L.) Moench] germplasm collection. Annals of Appl. Biol., 126 (3): 539-550.

Campos ET, Espinosa MAG, Warburton ML, Monter AV 2005. Characterisation of mandarin (Citrus spp) using morphological and AFLP markers, Interciencia 30(11):114.

Chattopadhyay A, Dutta S, Chatterjee S 2011. Seed yield and quality of okra as influenced by sowing dates. Afr. J. Biotechnol. 10:5461-5467.

Daniela, F. O., M. Alicia, R. C. Alicia, H. Rodolfo and Z. V. Sonia. 2012. Quality attributes of okra (Abelmoschus esculentus L. Moench) pods as affected by cultivar and fruit size. Journal of Food Research, 1(4), 224-235.

Das, S, A, Chattopadhyay, S. B. Chattopadhyay, S. Dutta and P. Hazra. 2013. Breeding okra for higher productivity and yellow vein mosaic tolerance. International Journal of
Vegetable Science, 19, 58-77.

Dhaduk, L. K., Mehta, D. R. and Patel, K. D. 2004. Genetic diversity in okra. The Orissa J. Horti., 32 (1): 70-72.

Esthiet JA, Brisibe AE 2015. Morphological Characterization and Yield Traits Analysis in Some Selected Varieties of Okra (Abelmoschus esculentus L. Moench). Adv. Crop. Sci. Technol. 3(5):1-5.

FAOSTAT. 2010. Economic and Social Department. The Statistics Division. Major Food and Agricultural Commodities and Producers.

Hazara, P., Basu, D. and Sahu, F.K. 2002. Genetic divergence in okra. Indian J. Hort., 59: 406410.

Ijoyah, M. O. and D. M. Dzer. 2012. Yield Performance of okra (Abelmoschus esculentus L. Moench) and maize (Zea mays L.) as affected by time of planting maize in Makurdi, Nigeria. Agriculture and Biological Journal of North America, 1(6), 1328- 1332.

John, M. S., George, W. and Mc Collum, J. P. 1992. Producing Vegetable Crops. (4th edn.) International Book Distribution Co. Lucknow.

Kishor, D. S., K. Arya, K. J. Yogeesh, K. Y. Vinod and K. Hee-Jong. 2016. Genotypic variation among okra (Abelmoschus esculentus (L.) Moench) germplasms in South Indian Plant Breeding and Biotechnology, 4(2), 234-241.

Kumar, P. S. \& S. Sreeparvathy 2010. Studies on heterosis in okra (Abelmoschus esculentus (L.) Moench). Electronic Journal of Plant Breeding 1(6), 1431-1433.

Kumari, M. and Chaudhury, D. N. 2006. Genetic divergence in okra [Abelmoschus esculentus (L.) Moench]. Veg. Sci., 33 (1): 71-72.

Mahalanobis, P. C. 1936. On the generalized distance in statistics. Proceedings of the National Institute of Science of India, 2, 49-55.

Mishra, S. N., Dash, S. N. and Mishra, D. 1996. Multivariate analysis of genetic divergence in okra (Hibiscus esculentus). Indian J. Agric. Sci., 66 (8): 502-503.

Muhammad, R. S., A. Muhammad, Z. Khurram, M. J. Muhammad, A. Saeed, I. Qumer and 
N. Aamir 2013. Growth, yield and seed production of okra as influenced by different growth regulators. Pakistan Journal of Agricultural Science, 50(3), 387392.

Murthy, B.R. and Anand, I.J. 1966. Combining ability and genetic divergence in some varieties of Linum usitatissimum. Indian J. Genet., 26: 21-26.

Ogunbayo SA, Ojo DK, Guei R, Oyelakin OO, Sanni KA 2005. Phylogenetic diversity and relationships among 40 rice accessions using morphological and RAPDs techniques. Afr. J. Biotechnol. 4(11):12341244.

Omonhinmin, C.A., and Osawaru M.E. 2005. Morphological characterization of two species of Abelmoschus: Abelmoschus esculentus and Abelmoschus caillei. Genet. Resour. Newsl. 144: 5155.

Pillai, S.V. 2002. Variability and genetic diversity in exotic germplasm of cassava (Manihot esculenta Crantz). Indian J. Genet., 62: 242-244.

Pradip, K., D. K. Akotkar and A. K. De Pal. 2010. Genetic variability and divergence in okra [Abelmoschus esculentus (L).Moench]. Electronic Journal of Plant Breeding, 1(4), 393-398.

Rahman K, Waseem M, Kashif MS, Jilani M, Kiran G 2012. Performance of different okra (Abelmoschus esculentus L.) cultivars under the agro-climatic conditions of Defra Ismail Khan. Pak. J. Sci. 64:316-319.

Rao, C.R. 1952. Advanced statistical method in biometrical research. John Wiley and Sons, New York.

Reddy, M. T., Haribabu, K., Ganesh, M., Reddy, K. C. and Begum H. 2012. Genetic divergence analysis of indigenous and exotic collections of okra (Abelmoschus esculentus (L.) Moench). J. Agric. Technol., 8 (2): 611-623.

Reddy, M. T., K. H. Babu, M. Ganesh, H. Begum, R. S. K. Reddy and J. D. Babu 2013. Exploitation of hybrid vigour for yield and its components in okra [Abelmoschus esculentus (L.) Moench]. American Journal of Agricultural Science and Technology, 1, $1-17$.

Ren J, McFerson J, Kresovich RLS and Lamboy WF 1995. Identities and Relationships among Chinese Vegetable Brassicas as Determined by Random Amplified Polymorphic DNA Markers. 120(3): 548555.

Saifullah, M. and Rabbani, M. G. 2009. Evaluation and Characterization of Okra (Abelmoschus esculentus L. Moench.) Genotypes. SAARC J. Agri., 7 (1), 92-99.

Seth, T., A. Chattopadhyay, S. Chatterjee, S. Dutta and B. Singh 2016. Selecting parental lines among cultivated and wild species of okra for hybridization aiming at YVMV disease resistance. Journal of Agricultural Science and Technology. 18, 751-762.

Umrao, V., S. K. Sharma, R. Kumar, V. Kumar and A. Sharma 2014. Genetic variability and divergence anal ysis in okra [Abelmoschus esculentus (L.) Moench]. HortFlora Research Spectrum, 3(2), 127132.

Vahab, M. A., Devi, S.N., Mathew, S. K. and Prabhakaran, P. V. 1994. Genetic divergence in okra [Abelmoschus esculentus (L.) Moench]. Hort. J., 7 (2): 117-120.

Yonas M, Garedew W, Debela A 2014. Maltivariate analysis among Okra (Abelmoschus esculentus L. Moench) Collections in South Western Ethiopia. J. Plant Sci. 9(2):43-50.

\section{How to cite this article:}

Davinder Singh, B.S. Dudi, S.K. Dhankhar and Rajkumar. 2018. Genetic Diversity Analysis of Okra Genotypes Using Morphological Markers. Int.J.Curr.Microbiol.App.Sci. 7(01): 16671675. doi: https://doi.org/10.20546/ijcmas.2018.701.202 